Chicago-Kent College of Law

Scholarly Commons @ IIT Chicago-Kent College of Law

January 2015

\title{
Women and Justice for the Poor: A History of Legal Aid, 1863-1945
}

Felice J. Batlan

IIT Chicago-Kent College of Law, fbatlan@kentlaw.iit.edu

Follow this and additional works at: https://scholarship.kentlaw.iit.edu/fac_schol

Part of the Law and Gender Commons, Law and Society Commons, and the Legal History Commons

\section{Recommended Citation}

Women and Justice for the Poor: A History of Legal Aid, 1863-1945 (Cambridge University Press 2015).

This Book Chapter is brought to you for free and open access by the Faculty Scholarship at Scholarly Commons @ IIT Chicago-Kent College of Law. It has been accepted for inclusion in All Faculty Scholarship by an authorized administrator of Scholarly Commons @ IIT Chicago-Kent College of Law. For more information, please contact jwenger@kentlaw.iit.edu, ebarney@kentlaw.iit.edu. 


\section{Introduction}

This book began in New Orleans amid the debris and destruction of Hurricane Katrina. In 2005, when the storm struck, I was living in New Orleans and teaching at Tulane University. The weeks after the storm were a confusing jumble of friends' couches, searches for clothing, and a growing sense that this would not end soon and that I would;need to occupy my time until the university reopened. Doing something in New Orleans seemed better than passively watching the continuing disaster on CNN, so I moved back into my damaged but still standing home. As someone actually living in New Orleans when much of the city was unoccupied and in ruins, I received constant calls from acquaintances, friends, and friends of friends who were unable to return to the city. People needed help with insurance forms and mortgages, with locating relatives, procuring housing, finding documents, and, above all else, dealing with the Federal Emergency Management Agency (FEMA) and its arbitrary and changing policies and procedures. In the wake of such an enormous catastrophe and the haphazard response by the government, many people needed a witness and advocate on the ground.

FEMA established a series of disaster recovery centers in and around New Orleans that were intended to function as "supermarkets" for hurricane aid. In these centers, victims could apply for FEMA benefits; procure information on repairing a roof; speak to the Army Corps of Engineers; receive a disaster tax rebate; find a Bible, a hot meal, a friendly ear. In theory, the centers were an excellent idea; in practice, they resulted in hundreds of people waiting in long lines for hour after hour. One day I approached a FEMA manager, handed her my résumé, and asked if I could set up a legal-information booth. She allowed me to do so without 
asking a single question. The "booth" consisted of a folding table and my cell phone. I organized a handful of attorney friends, and we staffed our station six days a week for two months.

I noticed that of the thousands of people who stopped by, few needed anything that I understood to be legal advice. A series of complicated emergency rules temporarily allowed volunteer attorneys like myself to practice law. Yet I had no clear understanding of whether I was covered by those rules or for whom I worked. Nor did I have the resources or expertise to practice law in any traditional sense. Instead, I functioned as a sort of mediator, personal advocate, legal educator, and social worker.

People came to our booth because they were desperately frustrated and needed help in whatever form it would come. Victims would call their insurance companies and be put on hold indefinitely; by the time somebody answered, the callers would be too infuriated to speak and would hand the phone to me. I would try to argue that a policy covered a particular type of damage, but often all I could do was schedule an appointment for an agent to inspect a damaged home. At times I had to document that a check from an insurance company or FEMA could not be mailed to a victim's address because that home no longer existed.

More often I mediated between FEMA representatives and people applying for benefits, and tried to understand how FEMA was interpreting its ever-changing rules. I informed inexperienced FEMA workers what the agency's policies were on that day, and alerted FEMA employees, all working in the same room, that they were interpreting policy in diametrically opposed ways. Most of all, I listened to people's stories, as the storm produced as many stories as there were survivors. Narrating their stories seemed crucial to those who were trying to process events that had happened so quickly, and people needed someone to hear and validate their experiences.

As time went on, those still seeking assistance were even more desperate for housing and funds. These were people who were poor before the storm but now were destitute. I spent time procuring FEMA trailers for those still homeless. Even if FEMA approved, shipped, and notified an applicant that a trailer was at a particular location and ready for occupancy, it did not mean that in reality the trailer was present or habitable. I tracked down missing trailers, asked why plumbing did not work, why the key did not fit the lock. At the very end, I simply tried to find vacant motel rooms - paid for by FEMA - but this did not provide a permanent solution for victims. On the worst days, I helped people obtain relatives' death certificates. 
This work made me reflect on what I was doing and whether I was using my legal knowledge, legal skill, or anything else that I had learned in law school or during my decade as a legal practitioner. In the FEMA center, law and social work bled together. My work seemed similar to that performed by many women's organizations in the late nineteenth and early twentieth centuries. ${ }^{\mathrm{I}} \mathrm{I}$ was doing what had to be done. I was helping because people needed help. I certainly had no sense that my work had anything to do with justice; there was little that was just in the entire situation.

I want to believe that I made some people's lives a bit easier for a brief amount of time, yet I was the greatest beneficiary. During the hours that I spent in the center, I was transformed from a hurricane victim into a professional with authority and expertise that made other people, especially inexperienced FEMA personnel, pay attention. I also understood that this authority was partially an illusion based on my status as a lawyer and law professor, my whiteness, and my class. My legal-assistance project made me reflect broadly on volunteer work, charity, lawyers, social workers, and the ambiguities of what the practice of law means in an environment of massive and aching need.

The development of organized free legal aid for the poor in the United States has a rich history that has been overlooked, even buried. Women and Justice for the Poor uncovers the enormous role played by women as legal aid providers in the late nineteenth and early twentieth centuries. It explores how ideologies of gender shaped and constructed what legal aid was and who would be its providers and clients. This book exposes the "real" history of legal aid, a story that the predominantly male leaders in the field of legal aid intentionally masked.

By beginning this history with nineteenth-century women's organizations, we see how they played central roles in the creation of urban legal institutions and how their leaders understood that legal aid needed to be part of a wider reform agenda. In the past, historians of women have brilliantly explored how such organizations engaged in significant and wide-ranging social-reform activities, from suffrage and temperance work to the creation of settlement houses, kindergartens, reform schools, benefit programs, and playgrounds. ${ }^{2}$ This body of work is large and rich,

I On gender and Hurricane Katrina, see the special issue of the journal of the National Women's Studies Association, NWSA Journal 20, no. 3 (2009).

2 The literature on women's clubs is enormous. Just a few examples include Anne Firor Scott, "Most Invisible of All: Black Women's Voluntary Associations," Journal of Southern History 56 (February I990): 3-22; Anne M. Boylan, The Origins of Women's 
but it does not explicitly see such organizations as crucial and innovative legal institutions. On the other hand, most legal historians have paid little attention to such women's organizations; from the perspective of traditional legal history, they are largely invisible. This book frames a dialogue between the all-too-separate fields of women's history and legal history. It is simultaneously a much-needed institutional history of legal aid.

We begin by exploring how, in the later decades of the nineteenth century, women's organizations pioneered the provision of legal aid in major cities such as New York, Boston, Chicago, and Philadelphia. Although the actual everyday delivery of such aid was carried out primarily by upper- and middle-class women who were not professional lawyers, their work eventually created a female and feminized "dominion" of legal aid. ${ }^{3}$ These early organizations specialized in claims on behalf of poor women - first addressing mostly wage claims against employers and then expanding to domestic relations cases and other legal problems. Such organizations defined legal assistance broadly, to include multiple kinds of advice as well as the provision of material aid. They also situated legal assistance within a wider agenda that included equality for women in the workplace, the home, and the public sphere. As practiced by women's organizations, the provision of legal aid intentionally entailed the legal

Activism: New York and Boston, I797-I840 (Chapel Hill: University of North Carolina Press, 2002); Nancy Schrom Dye, As Equals and as Sisters: Feminism, Unionism, and the Women's Trade Union League of New York (Columbia: University of Missouri Press, 1980); Ellen Fitzpatrick, Endless Crusade: Women Social Scientists and Progressive Reform (New York: Oxford University Press, I990); Sarah Deutsch, Woman and the City: Gender, Space, and Power in Boston, I870-1940 (New York: Oxford University Press, 2000); Maureen Flanagan, Seeing with Their Heart: Chicago Women and the Vision of the Good City (Princeton, NJ: Princeton University Press, 2002); Sara Monsoon, "The Lady and the Tiger: Women's Electoral Activism in New York City before Suffrage," Journal of Women's History 2 (Fall 1990): roo; Landon Storrs, Civilizing Capitalism: The National Consumers' League, Women's Activism, and Labor Standards in the New Deal Era (Chapel Hill: University of North Carolina Press, 2000); Karen Blair, The Clubwoman as Feminist: True Womanhood Redefined I868-I9I4 (Teaneck, NJ: Holmes and Meier Publishers, I980); Sandra Haarsager, Organized Womanhood: Cultural Politics in the Pacific Northwest, 1840-1920 (Norman: University of Oklahoma Press, 1997); Lara Vapnek, Breadwinners: Working Women and Economic Independence, $1865-1920$ (Urbana: University of Illinois Press, 2009).

3 Robyn Muncy's canonical Creating a Female Dominion in American Reform,-1890-I935 (New York: Oxford University Press, I99I) describes the work of a series of women's organizations and the reforms that they sought. Although Muncy does not discuss legal aid, her concept of creating a female dominion - in this case, one in child welfare that existed in an otherwise male empire of policymaking - is particularly apt in describing the history of legal aid and how female volunteers and social workers negotiated with a variety of male legal institutions. 
equivalent of a laying on of hands. That is, the connections and interactions between poor women and women lay lawyers helped heal class rifts, and they took place in an environment in which poor women could freely tell their stories. With time and experience, women lay lawyers acquired legal knowledge and positioned themselves as experts in the law, a stance that some male lawyers, and judges, accepted and even respected.

Following the creation of women's legal aid organizations, a second generation of legal aid associations developed in the late nineteenth and the early twentieth century. These societies generally were controlled by men, they primarily employed professional male lawyers, and they provided legal assistance to both men and women. As a number of male legal aid lawyers gained prominence, they sought to professionalize legal aid and transform it from its status as a charity - with its female dominion of lay lawyers - to something more akin to the private practice of law.

The history of legal aid thus fits into a much larger pattern of men professionalizing women's work and then using that professionalism to exclude women. ${ }^{4}$ These new legal aid leaders redrew the conventional image of the legal aid client; rather than a poor woman with a domestic relations claim, the client was now a working man with a wage claim. Such manly clients were entitled to legal aid as a means to establish their independence. Many clients of second-generation legal aid societies were immigrants, and attorneys imagined that the provision of legal assistance to these men served as a lesson in citizenship. This process of reconfiguring legal aid obscured women's presence as clients, lay lawyers, and even professional lawyers. Moreover, new legal aid organizations began to reject the types of claims, especially those involving domestic relations, that women typically sought to bring.

Picking up on and synthesizing what was already occurring within legal aid, Reginald Heber Smith's Justice and the Poor (I9I9) was the first extended "history" of legal aid. It was written to curry favor with bar associations and to disassociate legal aid from philanthropy, women's

4 The paradigmatic case of this phenomenon is in medicine. See, e.g., Regina MorantzSanchez, Medicine on Trial in Turn-of-the-Century Brooklyn (New York: Oxford University Press, I999); Leslie J. Reagan, When Abortion Was a Crime: Women, Medicine, and Law in the United States, 1867-1973 (Berkeley: University of California Press, 1998). In connection with nineteenth-century charity work, see Michael Katz, In the Shadow of the Poorhouse: A Social History of Welfare in America, 2nd ed. (New York: Basic Books, I996), 65; Eileen Boris and Jenifer Klein discuss this appropriation in relationship to the care of the disabled as medical doctors pushed out social workers, in Caring for America: Home Health Workers in the Shadow of the Welfare State (New York: Oxford University Press, 2012). 
organizations, and lay lawyers. ${ }^{5}$ Moreover, Smith believed that lawyers (especially graduates of elite law schools) had unique skills and training far beyond anything possessed by women lay lawyers or even women professional lawyers, no matter their experience. Smith hoped, further, that allying legal aid with bar associations would place legal aid in a manly sphere of law and thus generate prestige and financial support. Justice and the Poor succeeded in part - it essentially became scripture, providing legal aid with a usable past and a blueprint for the future. Generations of scholars have accepted Justice and the Poor as an accurate account of the history of legal aid. ${ }^{6}$ Within legal aid circles, Smith's work is still hailed for its originality and thorough research. 7 That legal scholars have missed the connections between women's organizations and the development of legal aid is proof of how well Smith and others hid them. Moreover, unlike later male-led legal aid organizations, the documentation of legal aid organizations run by women is sparse, buried in archival material seemingly unrelated to law, and consisting primarily of annual reports.

In the midst of the reconfiguration and professionalization of legal aid, social work first appeared as a profession, and at least some women lay lawyers began to consider themselves social workers. ${ }^{8}$ Male leaders

5 Reginald Heber Smith, Justice and the Poor (New York: Carnegie Foundation, I9r9).

6 See, e.g., Michael Grossberg, Counsel for the Poor? Legal Aid Societies and the Creation of Modern Urban Legal Structure, 1900-r930 (Vancouver: University of British Columbia, 1994); Jerold S. Auerbach, Unequal Justice: Lawyers and Social Change in Modern America (New York: Oxford University Press, I977); Martha Davis, Brutal Need: Lawyers and the Welfare Rights Movement, 1960-1973 (New Haven, CT: Yale University Press, 1995); Phillip Merkel, "At the Crossroads of Reform: The First Fifty Years of Legal Aid," Houston Law Review 27 (I990): ' 1-44; Earl Johnson Jr., Justice and Reform: The Formative Years of the American Legal Services Program (New York: Russell Sage Foundation, 1974); Jack Katz, Poor People's Lawyers in Transition (New Brunswick, N.J.: Rutgers University Press, I982); Deborah L. Rhode, Access to Justice (New York: Oxford University Press, 2005); Mark Spiegel, "The Boson Legal Aid Society: 1900-1925," Massachusetts Legal History 9 (2003): 17-48; Richard L. Abel, "Law Without Politics: Legal Aid under Advanced Capitalism," UCLA Law Review 32 (I985): 474-642.

7 See Earl Johnson Jr., To Establish Justice for All: The Past and Future of Civil Legal Aid in the United States, vol. I (Santa Barbara, CA: Praeger, 2014).

8 On the development of social work, see Daniel J. Walkowitz, Working with Class: Social Workers and the Politics of Middle-Class Identity (Chapel Hill: University of North Carolina Press, 1999); Elizabeth N. Agnew, From Charity to Social Work: Mary E. Richmond and the Creation of the American Profession (Urbana: University of Illinois Press, 2004); Muncy, Creating a Female Dominion; Katz, In the Shadow of the Poorbouse; Ellen Fitzpatrick, Endless Crusade; John H. Ehrenreich, The Altruistic Imagination: A History of Social Work and Social Policy in the United States (Ithaca, NY: Cornell University Press, I985). 
of legal aid quickly concluded that social workers should have little or no role in providing legal assistance. Yet social workers and their often female lawyer allies contested the project to masculinize legal aid and situate it in the professional world of lawyers. They asserted their own authority over providing legal aid, especially with the development of specialized juvenile and domestic relations courts, which were often staffed by female social workers and lay lawyers. ${ }^{9}$ New schools of social work began to teach law to their predominately female students, with the idea that these students would provide legal services to the poor.

By the early r920s, male leaders in legal aid panicked over legal aid's relationship to social work, their concerns linked to issues of gender, authority, expertise, and professionalization. The resulting controversy raised questions about what constituted the practice law, what the rule of law meant, what was a legal problem, what types of services legal aid should provide, and which clients legal aid should serve. Central to these issues was a fundamental question: Was legal aid meant to offer a process-based form of justice by allowing access to an attorney, or was it intended to create substantive justice? Although scholars of legal aid have long pointed to its conservative nature, social workers presented an alternative, more expansive version of legal aid based on ideas of social justice. In exploring these issues, Women and Justice for the Poor demonstrates how law and social work were in contest with each other, and how each helped to define the other in that opposition. It thus refuses to see law and social work as distinct disciplines - one largely male and the other largely female. ${ }^{\text {Io }}$

9 On these specialized courts, see David Tanenhaus, Juvenile Justice in the Making (New York: Oxford University Press, 2004); Michael Willrich, City of Courts: Socializing Justice in Progressive-Era Chicago (New York: Oxford University Press, 2003); Mae C. Quinn, "Feminist Legal Realism," Harvard Journal of Law and Gender 35 (2012): I-54.

To A recent work that elegantly puts social workers and medical professionals in dialogue is Eileen Boris and Jennifer Klein, Caring for America. Similarly, Susan D. Carle unearths and examines how African American lawyers, sociologists, and members of women's clubs engaged together in civil rights work, in Defining the Struggle: National Organizing for Racial Justice (Oxford: Oxford University Press, 2013). Karen Tani looks at debates between lawyers and social workers during the New Deal in "Securing a Right to Welfare: Public Assistance and the Rule of Law, I935-1965," PhD diss., University of Pennsylvania, 20Iт. Other works that explore interdisciplinary approaches to law in historical context include Christopher Tomlins, "Framing the Field of Law's Disciplinary Encounters: A Historical Narrative," Law and Society Review 34 (2000): 9r I; Laura Kalman, Legal Realism at Yale, 1927-1960 (Chapel Hill: University of North Carolina Press, I986). 
Placing women, as both legal aid providers and clients, at the center of this history forces us to reexamine some of our fundamental assumptions about the development of the American legal profession and the relationship and boundaries between "professional" lawyers and "lay lawyers." Specifically, this book questions what it means to "practice law" and blurs the conventional division between lawyer and nonlawyer. ${ }^{\text {II }}$ Although traditionally we have believed that, from the late nineteenth century onward, bar associations actively policed the practice of law, for decades bar associations knew but did nothing about the fact that women lay lawyers and social workers were engaged in a wide variety of legal activities. ${ }^{\mathrm{I} 2}$ The neat conventional narrative of the legal profession's steady monopolization of legal services looks messier when we acknowledge the roles that social workers played in legal aid organizations. Likewise, the book's geography or locus of inquiry is not spectacular courtroom trials but office practice, the provision of everyday legal advice, and the mediation of legal claims. ${ }^{\text {I3 }}$. Similarly it is not about legal doctrine; rather, it provides a new way of thinking about the legal profession and the practice of law. From such different perspectives, the practice of law was more democratic and heterogeneous - and less male - than we understood it to have been.

How legal aid developed reflected larger societal tensions and contradictions involving the role of women and how gender functioned in society. ${ }^{14}$ In the nineteenth and twentieth centuries, gender served as both a practice and a discourse through which people articulated, constructed, and defined rights and obligations. As a relational construct, it symbolized, mobilized, and even subverted power. ${ }^{\mathrm{I}}$ This book examines how historical actors spoke and wrote about manhood and womanhood and

II W. Wesley Pue and David Sugarman have written that the category of lawyers might actually include a wide variety of subgroups, and the demarcations between lawyers and nonlawyers are often historically contingent. See "Introduction: Towards a Cultural History of Lawyers," in Lawyers and Vampires: Cultural Histories of Legal Professions, ed. Pue and Sugarman (Oxford: Hart Publishing, 2003), 9.

12 For a classic account of the historical development of bar associations, see Michael Powell, From Patrician to Professional Elite: The Transformation of the New York City Bar Association (New York: Russell Sage Foundation, 1988); Auerbach, Unequal Justice; Terrence C. Halliday, Beyond Monopoly: Lawyers, State Crises, and Professional Empowerment (Chicago: University of Chicago Press, 1987).

I3 See Kenneth W. Mack, Representing the Race: The Creation of the Civil Rights Lawyer (Cambridge, MA: Harvard University Press, 2012).

I4 Joan Scott, "Feminism's History," Journal of Women's History I6 (2004): ro-29, 20.

I5 There is a vast literature on gender and history; see, e.g., Joan Scott, "Gender: A Useful Category of Historical Analysis," American Historical Review 9x (December 1986): 
what they claimed in connection with those ideas - and it also articulates how gender systems had real material consequences. The very terms social work, charity, and profession are gendered, insofar as they carry connotations of men's and women's appropriate roles and social and professional hierarchies. ${ }^{16}$ Gender even defined whose labor was valued and visible and whose labor was not - or whose could not be recognized without subverting dominant gender constructs. ${ }^{17}$

This study also engages with an expanding and important literature on the history of women lawyers. Scholars have documented the story of the miniscule number of women who began seeking admission to the bar in the $x 870$ s after having read law. Other women in the $1880 \mathrm{os}$ and 1890 os began applying for entrance into law schools. These women pioneers fought with law schools for admission, and battled courts and legislatures to permit women to sit for bar examinations and then be admitted into a state's bar. ${ }^{18}$ State and federal courts found that the

I053; Linda K. Kerber, No Constitutional Rights to Be Ladies: Women and the Obligation of Citizenship (New York: Hill and Wang, I998); Barbara Young Welke, Recasting American Liberty: Gender, Race, Law, and the Railroad Revolution (Cambridge: Cambridge University Press, 2001); Kevin Murphy, Political Manbood: Red Bloods, Mollycoddles, and the Politics of Progressive-Era Reform (New York: Columbia University Press, 2008); Christopher Dummitt, The Manly Modern: Masculinity in Postwar Canada (Vancouver: University of British Columbia Press, 2007); Joanne Meyerwitz, "A History of 'Gender," American Historical Review I 3 (December 2008): I346-56; Tracy A. Thomas and Tracey Jean Boisseau, eds., Feminist Legal History: Essays on Women and the Law (New York: New York University Press, 20I I).

${ }^{16}$ See, e.g., Mary Ryan, Women in Public: Between Banners and Ballots, I825-1880 (Baltimore: Johns Hopkins University Press, r990); Rebecca Edwards, Angels in the Machinery: Gender in American Party Politics from the Civil War to the Progressive Era (New York: Oxford University Press, I997); Laura Edwards, Gendered Strife and Confusion: The Political Culture of Reconstruction (Urbana: University of Illinois Press, r997).

17 See, e.g., Elizabeth Faue, "Reimagining Labor: Gender and New Directions in Labor and Working-Class History," in Continuum Companion to United States Labor History, ed. Donna Haverty-Stacke and Daniel J. Walkowitz (New York: Continuum International Publishers, 2010); Eileen Boris and Rachel Salazar Parreñas, eds., Intimate Labors: Care, Sex, and Domestic Work (Stanford, CA: Stanford University Press, 2010).

${ }^{18}$.See Jill Norgren, Rebels at the Bar: The Fascinating, Forgotten Stories of America's First Women Lawyers (New York: New York University Press, 2013); Barbara Babcock, Woman Lawyer: The Trials of Clara Foltz (Stanford, CA: Stanford University Press, 20II); Jill Norgren, Belva Lockwood: The Woman Who Would Be President (New York: New York University Press, 2007); Mary Jane Mossman, The First Women Lawyers: A Comparative Study of Gender, Law, and the Legal Profession (Oxford: Hart Publishing, 2006); Virginia Drachman, Women Lawyers and the Origins of Professional Identity in America (Ann Arbor: University of Michigan Press, r993); Karen M. Tani, "Portia's Deal," Chicago-Kent Law Review 87. (201 2): 549-70; Gwen Jordan, "Engendering the History of Race and International Relations: The Career of Edith Sampson, 
Fourteenth Amendment did not require states to admit women to the bar, just as it did not give them the right of suffrage. ${ }^{19}$ Those opposed to women lawyers reasoned that if a woman lawyer was permitted to represent others, why couldn't she represent herself and therefore vote, be a juror, or hold public office? Women's entry to the legal profession was thus a slippery slope to full citizenship. But even as legal barriers dropped, female lawyers well into the twentieth century found scarce employment opportunities; some found work by joining legal aid organizations or establishing solo practices that represented the poor.

Although groundbreaking, the literature on women lawyers prioritizes their professional status in shaping our understanding of what it meant for women to practice law, and in the process it leaves unexplored a much larger field of women's legal activities. When we look only at professional women attorneys, the history of women in the law appears to be one of slow but steady progress from the late nineteenth and into the twentieth century. In contrast, when we include women lay lawyers and, later, social workers in the analysis, the conventional story of progress over time becomes less linear and more complicated, revealing periods of declension that bring the narrative of progress into question.

Likewise, scholars have recently begun to study the role of race in the provision of legal assistance. ${ }^{20}$ Superficially, all the legal aid organizations examined in this book claimed to accept cases without regard to race, religion, or creed. Such pronouncements were important to these organizations, as they confirmed that justice was available to all. Yet in decades' worth of legal aid material, there is little discussion of African Americans either as clients or legal aid providers. In fact, among women's organizations the very claim to legal authority was partly based on their members' whiteness. The providers of legal aid, whether lay lawyers or professionals, were primarily white, creating a complicated nexus of race, ethnicity, gender, and class.

African Americans, however, certainly used the services of legal aid organizations. The Legal Aid Society of Chicago employed publicity

1927-1978," Chicago-Kent Law Review 87 (2012): 521-48; Phyllis Eckhaus, "Restless Women: The Pioneering Alumnae of New York University School of Law," New York University Law Review 66 (I991): 1996-2013.

I9 See Bradwell v. Illinois, 83 U.S. I30 (I 873); Minor v. Happersett, 88 U.S. I62 (I 875 ).

20 Shaun Ossei-Owusu, Law's Underbelly: Legal Aid from Slavery to Mass Incarceration, PhD diss., University of California, Berkeley, 20I4; Kris Shepard, Rationing Justice: Poverty Lawyers and Poor People in the Deep South (Baton Rouge: Louisiana University Press, 2007); Carle, Defining the Struggle; Mack, Representing the Race. 
photographs that clearly depicted African American clients. Yet, as we shall see, other organizations adopted supposedly neutral eligibility policies that had the effect of limiting the number of African American clients. Most blatantly, legal aid was slow to grow in the South, where it was feared that even the smallest claims of African Americans against whites would subvert white supremacy. Whether in the North or the South, none of the legal aid organizations examined here saw the dismantling of racial discrimination as being within their purview. Across decades, legal aid organizations studiously separated the everyday provision of legal aid from cases that overtly challenged white supremacy.

This book examines only organizations that specifically understood and identified themselves as providing free; organized, civil legal aid to the poor on a continual basis. Undoubtedly, many individual lawyers provided such assistance on occasion, and organizations such as mutual aid societies, churches, labor unions, settlement houses, and a vast array of social service agencies provided some legal assistance. For instance, male African American lawyers held high positions in black fraternal orders; it is certainly possible that such orders provided legal assistance to members. ${ }^{2 I}$ The poor, especially immigrants who were not from Western Europe, and racial minorities may have looked first to this wide array of other organizations before turning to established legal aid organizations. Although this book at times points to those alternative institutions, it leaves to others the important work of uncovering the full range and mix of legal assistance.

The provision of free legal aid to the poor was not unique to the United States, but it flourished in America. ${ }^{22}$ Paralleling John Fabian Witt's conclusions regarding insurance and personal injury cases in the late nineteenth century, it is clear that the growth of legal aid was propelled indirectly by the lack of powerful unions (especially for women) and the absence of strong state regulation or a robust administrative bureaucracy. ${ }^{23}$ Issues of small and great consequence depended on bringing or at least threatening to bring individual lawsuits. The largest

2I Theda Skocpol, Ariane Liazos, and Marshall Ganz, What a Mighty Power We Can Be: African American Fraternal Groups and the Struggle for Racial Equality (Princeton, NJ: Princeton University Press, 2006).

22 See Henning Grunwald, Courtroom to Revolutionary Stage: Performance and Ideology in Weimar Political Trials (Oxford: Oxford University Press, 2012).

23 John Fabian Witt, The Accidental Republic: Crippled Workingmen, Destitute Widows, and the Remaking of American Law (Cambridge, MA: Harvard University Press, 2004). See also Theda Skocpol, Protecting Soldiers and Mothers: The Political Origins of Social Policy in the United States (Cambridge, MA: Belknap Press of Harvard University Press, 
category of legal aid claims in the nineteenth and early twentieth centuries involved employees' wages; the second largest involved domestic relations. Yet the weak state does not fully explain the phenomenon of legal aid, because the later development of the administrative state and even the "semi-welfare state" of the I960s did not retard the growth or use of legal aid organizations. ${ }^{24}$

From one perspective, legal aid stood at the margins of the legal profession because it ministered to the poor and least empowered. Some studies imply that legal aid organizations were moribund until the I960s, when federal funds began to flow to legal aid and an energetic cadre of young lawyers aligned with the New Left worked to revamp it. ${ }^{25}$ But long before the I96os, legal aid organizations provided services to an enormous number of people: from the 1870 o up until I938, such organizations handled more than five million cases. ${ }^{26}$ Throughout the twentieth century, the demand for legal aid consistently outpaced the capacity of legal aid organizations. As legal aid offices opened, people flocked to them.

Studying legal aid is not only important because of the vast number of clients served but also because it brought together men and women of all classes, from the poorest of the poor to some of the most elite lawyers in America. Well-known women's reform organizations, such as Boston's Women's Educational and Industrial Union and the Chicago Women's $\mathrm{Club}$, and some of the most prestigious bar associations, including the Association of the Bar of the City of New York (which long prohibited women lawyers from membership) appear here because legal aid brought them into (often confrontational) contact. Such legal luminaries as Roscoe Pound, Charles Evans Hughes, and Sophonisba Breckinridge were forced to reckon with one another's ideas of what constituted justice.

Legal aid could have transformative possibilities. It could permit lawyers to stand momentarily outside the market and allow upper- and middle-class women to function as lawyers; a desperately poor person

I995); Susan J. Pearson, The Rights of the Defenseless: Protecting Animals and Children in Gilded-Age America (Chicago: University of Chicago Press, 20II).

24 Michael Katz uses this term in In the Shadow of the Poorhouse, 242.

25 See, e.g., Johnson; Justice and Reform; Alan Houseman, "Political Lessons: Legal Services for the Poor - A Commentary," Georgetown Law Journal 83 (April 1995): I669.

26 National Association of Legal Aid Organizations, Reports of Committee, 1938-1939 (Rochester, I939), 29. In I939 NALAO stopped estimating the aggregate number of cases handled, understanding that such numbers were probably inaccurate because they did not include the work of many organizations and because of disagreement regarding. what counted as a case. 
could become a rights-bearing individual; an abused wife could find new stability. Legal aid also could be conservative: legal aid organizations often disciplined workers to fit into a capitalist, wage-based economy, and some of them put tremendous pressure on men to become steady breadwinners. Additionally, many organizations refused to handle divorce cases and failed to see wife beating as a serious problem. Instead, they worked to uphold the prerogatives of husbands. Such organizations were also hesitant to take the claims of domestic servants, thereby shielding the labor practices of elites. At moments, legal aid providers openly expressed a profound dislike for and distrust of their clients. They might deplore urban poverty, but few organizations before the r96os used the law to promote structural reforms that might eliminate either poverty or white supremacy. Instead, legal aid organizations were often founded in response to poor people's political and labor activities and represented an attempt to placate workers and elide class conflict. Where possible, this study draws on the voices of those seeking legal assistance, but for the most part it makes use of the documents of legal aid organizations, which were written, of course, by the providers of legal aid.

Finally, although Women and Justice for the Poor is a work of history, it speaks to the present as well. Legal aid is in crisis in the early twenty-first century, as government funding shrinks and poverty expands. Some controversial proposals to reinvigorate legal aid call for increasing the use of nonlawyers. ${ }^{27}$ Some advocates claim that the presence of lawyers may actually hinder the productive resolution of poor clients' legal problems because attorneys escalate disputes and create delays. ${ }^{28}$ Under the new model, legal services would focus more on mediating disputes and providing social services to clients, and less on the adversarial process and formal law. One of the leading voices in the access-tojustice community, Jeanne Charn, argues for a "functionalist, pragmatic approach" that would use lawyers only when specialized legal expertise is necessary. ${ }^{29}$ She claims that low-income people prefer readily available, informal advice from nonlawyers over formal advice from lawyers. The

27 Rhode, Access to Justice; Gillian Hadfield, "Summary of Testimony: Task Force to Expand Access to Civil Legal Services in New York, Chief Judge's Hearings, October I, 20I 2,". http://richardzorza.files.wordpress.com/201 $2 /$ ro/hadfield-testimony-october20I2-final-2.pdf.

28 Rebecca Aviel, "Why Civil Gideon Won't Fix Family Law," Yale Law Journal 22 (June 2013): 2106-24, 2II8-I9.

29 Jeanne Charn, "Celebrating the 'Null' Finding: Evidence-Based Strategies for Improving Access to Legal Services," Yale Law Journal 22 (June 2013): 2206-34, 2213. 
adversarial attorney-based model of law would be replaced by negotiation and problem solving. ${ }^{30}$ Likewise, scholars are beginning to question whether the legal profession should have a monopoly over law and how social workers and others might deliver legal assistance in a wide range of areas. ${ }^{3 \mathrm{I}}$

There is a long, hidden history of nonlawyers providing legal assistance along with social services. ${ }^{32}$ And there is no evidence that, historically, the work of nonlawyers was inferior to that of lawyers. Given this, we should ask why lawyers believe that they alone should handle the legal needs of the poor. Women and Justice for the Poor establishes a very different, more capacious view of legal aid grounded in women's history and legal history.

30 Ibid.

${ }^{31}$ See, e.g., Deborah L. Rhode and Lucy Buford Ricca, "Protecting the Profession or the Public? Rethinking Unauthorized-Practice Enforcement," Fordham Law Review 82 (2014): 2587-610; Jack Sahl, "Cracks in the Profession's Monopoly Armor," Fordham Law Review 82 (2014): 2635-63.

32 For an important older work that argues against such an approach while demonstrating the long history of mediation and arbitration in the United States, see Jerold S. Auerbach, Justice without Law (New York: Oxford University Press, I983). 